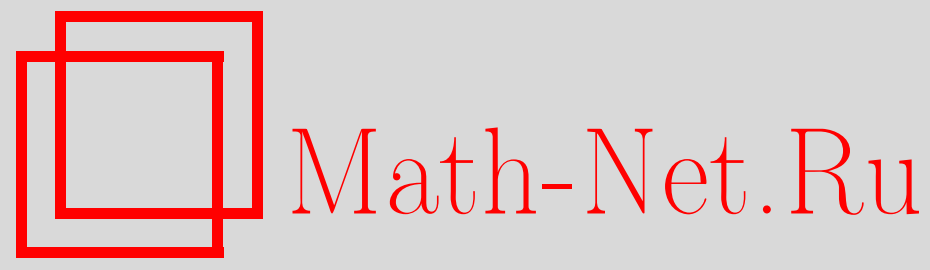

Нашему журналу 50 лет, Функи. анализ и его прил., 2017, том 51, выпуск 1, 3

DOI: https://doi.org/10.4213/faa3261

Использование Общероссийского математического портала Math-Net.Ru подразумевает, что вы прочитали и согласны с пользовательским соглашением http://www.mathnet.ru/rus/agreement

Параметры загрузки:

IP : 52.205.19.152

26 апреля 2023 г., 13:23:24

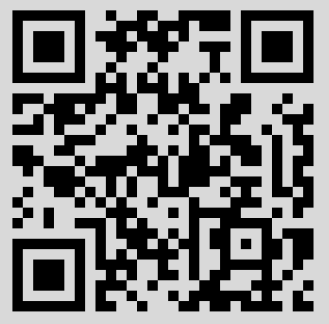




\section{Нашему журналу 50 лет}

В середине 60-х годов И. М. Гельфанд создал новый научный журнал: «Функциональный анализ и его приложения».

Первый номер журнала увидел свет в 1967 году, с тех пор вышло 200 номеров. Журнал сразу вошел в число наиболее авторитетных математических изданий в мире и сыграл очень большую роль в полноценном представлении достижений отечественной математики. Редакторомоснователем были заданы основные принципы работы журнала: широта тематики, подчас далеко выходящая за рамки буквально понимаемого названия и наглядно демонстрирующая глубокое единство математики, а также высокая требовательность к научному уровню и понятности текста. За это время в журнале было опубликовано 3180 работ (1213 статей и 1967 заметок), многие из которых стали классикой нашей науки.

Мы очень надеемся, что журнал и дальше сохранит верность своим традициям и принесет много пользы развитию математики и ее приложений. 